Original article

\title{
Genetic analysis for mastitis resistance and milk somatic cell score in French Lacaune dairy sheep
}

\author{
Francis BARILLET $^{\mathrm{a}, *}$, Rachel RUPP ${ }^{\mathrm{b}}$, \\ Sandrine Mignon-Grasteau ${ }^{\mathrm{a}, \mathrm{c}}$, Jean-Michel Astruc ${ }^{\mathrm{d}}$, \\ Michèle JACQUIN ${ }^{\mathrm{a}}$ \\ ${ }^{a}$ Station d'amélioration des animaux, Institut national de la recherche agronomique, \\ BP 27, 31326 Castanet-Tolosan Cedex, France \\ ${ }^{\mathrm{b}}$ Station de génétique quantitative et appliquée, Institut national de la recherche \\ agronomique, 78352 Jouy-en-Josas Cedex, France \\ ${ }^{c}$ Present address: Station de recherches avicoles, Institut national de la recherche \\ agronomique, 37380 Nouzilly, France \\ d Institut de l'élevage, BP 18, 31321 Castanet-Tolosan Cedex, France
}

(Received 14 September 2000; accepted 13 February 2001)

\begin{abstract}
Genetic analysis for mastitis resistance was studied from two data sets. Firstly, risk factors for different mastitis traits, i.e. culling due to clinical or chronic mastitis and subclinical mastitis predicted from somatic cell count (SCC), were explored using data from 957 first lactation Lacaune ewes of an experimental INRA flock composed of two divergent lines for milk yield. Secondly, genetic parameters for SCC were estimated from 5272 first lactation Lacaune ewes recorded among 38 flocks, using an animal model. In the experimental flock, the frequency of culling due to clinical mastitis (5\%) was lower than that of subclinical mastitis (10\%) predicted from SCC. Predicted subclinical mastitis was unfavourably associated with the milk yield level. Such an antagonism was not detected for clinical mastitis, which could result, to some extent, from its low frequency or from the limited amount of data. In practice, however, selection for mastitis resistance could be limited in a first approach to selection against subclinical mastitis using SCC. The heritability estimate of SCC was 0.15 for the lactation mean trait and varied from 0.04 to 0.12 from the first to the fifth test-day. The genetic correlation between lactation SCC and milk yield was slightly positive (0.15) but showed a strong evolution during lactation, i.e. from favourable ( 0.48$)$ to antagonistic $(0.27)$. On a lactation basis, our results suggest that selection for mastitis resistance based on SCC is feasible. Patterns for genetic parameters within first lactation, however, require further confirmation and investigation.
\end{abstract}

dairy sheep / somatic cell count / mastitis / genetic parameters / risk factors

\footnotetext{
* Correspondence and reprints

E-mail: Barillet@toulouse.inra.fr
} 


\section{INTRODUCTION}

In France, dairy sheep selection has been oriented towards milk yield, milk composition, and type traits. Little attention has been given to functional traits such as udder health. The economic importance of these functional traits, however, has increased rapidly in the last five years.

Mastitis is one of the main causes of culling of dairy ewes. Economic consequences of mastitis, either clinical or subclinical, include loss of milk production, alteration of cheese-making properties [30], increased culling rate, and increased cost and labour for detection and veterinary treatment. Furthermore, a high somatic cell count (SCC) in milk may reduce the price of milk for the farmer by more than $10 \%$ in the payment system implemented in the Roquefort area since 1997.

From the abundant literature data on dairy cattle [18,27,33], it appears that (i) SCC and clinical mastitis (CM) cannot be considered as the expression of the same trait, since their genetic correlation is around 0.7, (ii) selecting for SCC rather than for CM has several advantages: SCC is routinely recorded in most dairy cattle recording systems contrary to CM events (except in Scandinavian countries) and SCC has a higher heritability than CM (0.15 vs. 0.02), (iii) unfavourable genetic correlations between milk production and both SCC and $\mathrm{CM}$ have been reported, indicating that dairy selection should have reduced mastitis resistance in dairy cattle, and (iv) selection for decreased SCC should reduce susceptibility to both clinical and subclinical mastitis, but adding CM information would increase the efficiency of selection for udder health, and particularly for CM [13,24].

Conversely, genetic literature is limited for dairy sheep $[6,16,17,26]$ and not always in agreement with dairy cattle results. Intramammary infections in dairy sheep mainly differ from bovine infections by their etiology and by a lower incidence of clinical mastitis versus subclinical mastitis [8]. In both species, coagulase-negative staphylococci are usually the most frequently isolated germs in subclinical mastitis. They are, however, considered as minor pathogens in cattle, whereas, in dairy sheep, they are responsible for most cases of mastitis caught in milking parlours and consequently appear to be major pathogens in this species $[7,9,14,15,25,36]$.

The objective of this study was to carry out a genetic analysis for mastitis resistance in the French Lacaune breed to contribute towards defining a breeding strategy for udder health in dairy sheep. Firstly, a risk factor analysis was performed using data from an experimental flock. Secondly, genetic parameters for somatic cell counts were estimated from on-farm data. 


\section{MATERIALS AND METHODS}

\subsection{Data}

The data included records from first lactation Lacaune ewes collected, on the one hand, from an experimental INRA flock (La Fage, Roquefort) from 1992 to 1997, and on the other hand, from 38 official milk-recorded flocks from 1993 to 1997. The study was focused on the first lactation because these results are more informative and easier to interpret. Indeed, udders may be considered as uninfected before the first lambing whereas the udder status of adult ewes is much more dependent on strategies for culling and possible treatment at drying off.

The edited file from the experimental flock included 957 first lactation ewes belonging to two divergent lines, denoted High and Low. The lines had been selected for dry matter yield (fat and protein) since 1989, each year using the 10-20 top-ranked and bottom-ranked rams among 600 artificial insemination rams of the Lacaune breeding programme described by Barillet [3] to procreate 4-5 daughters per sire in the INRA experimental flock. In that way, the design corresponds to a pseudo-divergent selection of lines opened on the on-farm breeding programme. Consequently, the genetic difference between the two lines is limited to the difference in the estimated breeding value (EBV) between the two groups of sires (Tab. I): the EBVs are comparable for fat and protein content, while the divergence in milk yield is about $61.5 \mathrm{~L}$, i.e. almost two genetic standard deviations or 10 years of the estimated genetic trend in the French Lacaune breed evaluation [5]. In the experimental flock, individual SCCs were recorded every 2 or 3 weeks, at evening and morning milkings, as part of the milk recording. Daily SCCs were computed as the mean of evening and morning records. Dates and causes of culling (including clinical mastitis) were also routinely recorded by farm technicians. In addition, udder abnormalities were detected by mammary palpation carried out at the end of lactation.

The on-farm data included 5272 first lactation ewes from 38 flocks of the nucleus scheme where SCC was experimentally recorded with the financial support of a French and a European research contract. Ewes were recorded monthly using the AC method [21] after a 25-day suckling period. This method means that individual daily milk yield is estimated from individual morning recordings adjusted with the bulk tank milk of the 2 daily milkings [19]. Fat, protein, and SCC were measured from a sample of the morning milking [2]. The characteristics of the two data sets are presented in Tables II and III.

\subsection{Definition of traits}

Two traits pertaining to mastitis were considered. In the experimental flock, ewes affected by clinical mastitis (modification of the colour or consistency 
Table I. EBV of the sires of the High and Low lines (evaluation from May 2000).

\begin{tabular}{lcc}
\hline Characteristics & Low line & High line \\
\hline Number of females & 341 & 616 \\
Number of sires (sires per year) & $76(12.6)$ & $123(20.5)$ \\
Number of daughters per sire in the experimental flock & 4.5 & 5 \\
Number of daughters per sire for EBV & 48 & 639 \\
Reliability for milk yield & 0.733 & 0.953 \\
Reliability for fat or protein contents & 0.826 & 0.968 \\
EBV for milk yield (litres) & 3.2 & 64.7 \\
EBV for fat content $\left(\mathrm{g} \cdot \mathrm{L}^{-1}\right)$ & 0.46 & 0.64 \\
EBV for protein content $\left(\mathrm{g} \cdot \mathrm{L}^{-1}\right)$ & 0.66 & 0.59 \\
\hline
\end{tabular}

Table II. Structure and general statistics of the data sets.

\begin{tabular}{|c|c|c|}
\hline & $\begin{array}{c}\text { Experimental flock } \\
\text { data }\end{array}$ & $\begin{array}{l}\text { On-farm } \\
\text { data }\end{array}$ \\
\hline \multicolumn{3}{|l|}{ Characteristics } \\
\hline Study period & 1992-1997 & $1993-1997$ \\
\hline Number of flocks (flock $\times$ year combination) & $1(6)$ & $38(68)$ \\
\hline Number of first lactations & 957 & 5272 \\
\hline Number of test-days in first lactation & 5609 & 23091 \\
\hline \multicolumn{3}{|l|}{ Average performances ${ }^{(1)}$} \\
\hline Milk Yield (litres) & 217 & 221 \\
\hline Length of milking period (days) & 145 & 150 \\
\hline SCC (a.m. test-day), (cells $\cdot \mathrm{mL}^{-1}$ ) & 316000 & 374300 \\
\hline SCC (a.m. \& p.m. test-day), (cells $\cdot \mathrm{mL}^{-1}$ ) & 359500 & \\
\hline \multicolumn{3}{|l|}{ Proportion of ewes affected by mastitis } \\
\hline \multicolumn{3}{|l|}{ CCMAST $^{(2)}$ (average DIM at culling), $(\%)$} \\
\hline clinical mastitis & $3.6(32)$ & \\
\hline chronic mastitis & $1.7(129)$ & \\
\hline \multicolumn{3}{|l|}{$\operatorname{SUBMAST}^{(3)},(\%)$} \\
\hline "healthy" & 81.5 & 82 \\
\hline "doubtful" & 8.1 & 8 \\
\hline "infected" & 10.4 & 10 \\
\hline
\end{tabular}

(1) calculated from all the information from day in milk 25 until the end of the first lactation.

(2) CCMAST $=$ culling for clinical or chronic mastitis.

(3) SUBMAST = prediction of the subclinical mastitis status of the udder from SCC (level analysed: "infected" vs. "doubtful", "healthy" or no SCC available). 
Table III. Number of records and mean of lactation and single test-day traits for Milk Yield and SCS in first lactation (on-farm data) defined according to days in milk.

\begin{tabular}{|c|c|c|c|c|c|c|}
\hline \multirow[t]{2}{*}{ Trait } & \multicolumn{6}{|c|}{ Definition of analysed trait (DIM) } \\
\hline & $\begin{array}{c}\text { Lactation } \\
\text { Mean } \\
(\geq 25)\end{array}$ & $\begin{array}{c}\text { Test-day } \\
\# 1 \\
(25-54)\end{array}$ & $\begin{array}{c}\text { Test-day } \\
\# 2 \\
(55-84)\end{array}$ & $\begin{array}{c}\text { Test-day } \\
\# 3 \\
(85-114)\end{array}$ & $\begin{array}{c}\text { Test-day } \\
\text { \#4 } \\
(115-144)\end{array}$ & $\begin{array}{c}\text { Test-day } \\
\# 5 \\
(145-174)\end{array}$ \\
\hline Number of records & 5272 & 3896 & 5126 & 4937 & 3528 & 2595 \\
\hline Milk Yield (L) & 221 & 2.10 & 1.84 & 1.51 & 1.21 & 0.95 \\
\hline Somatic Cell Score & 3.29 & 3.08 & 3.16 & 3.33 & 3.40 & 3.43 \\
\hline
\end{tabular}

of the milk; hot, swollen or painful udder) were systematically culled shortly after disease occurrence. In addition, ewes showing udder abnormalities at mammary palpation were also culled. These abnormalities mostly included the drying off of one half-udder $(>70 \%)$, but also nodules, induration and a marked imbalance of the mammary gland. All such observations can be related to chronic mastitis [8]. To process this information, the binary variable CCMAST was defined as culling for either clinical or chronic mastitis $(=1)$ or no such culling $(=0)$. Since disease events were not recorded in the 38 official milk-recorded flocks, CCMAST was not defined in the on-farm data set. Additionally, monthly SCC records were used to predict the mastitis status (SUBMAST) of each first lactation ewe. As proposed by Bergonnier et al. [7], a ewe with all test-day SCC below 500000 cells $\cdot \mathrm{mL}^{1}$ (except one) was considered as "healthy" (SUBMAST=0), a ewe with at least two test-day SCC above 1000000 cells . mL ${ }^{1}$ was considered as "infected" (SUBMAST $=1)$, and, in other cases, ewes were classified as "doubtful" (SUBMAST = 2). Among the "infected" ewes, $6.6 \%$ were culled for chronic mastitis (CCMAST $=1)$, but $93.4 \%$ did not show visible signs of the disease. Conversely, none of the ewes culled for clinical mastitis were predicted as "infected" by SUBMAST. Indeed, culling for clinical mastitis occurred very early in lactation, mostly before the first test-day record. Therefore, SUBMAST mainly reflected subclinical infections, and, to a lower extent $(<7 \%)$, chronic mastitis.

For both data sets, a cell count lactation mean (LSCS) was computed as the arithmetic mean of test-day somatic cell score (SCS), adjusted for days in milk as proposed by Wiggans and Shook [39], and recorded from day in milk (DIM) 25, i.e. the end of the suckling period, until the end of the first lactation. Only ewes with all (except one) test-day SCC below 500000 cells $\cdot \mathrm{mL}^{1}$, i.e. "healthy" according to Bergonnier et al. [7], were taken into account to estimate adjustment factors. Because SCC has a highly skewed distribution, SCS was defined in a classical way [1] through a logarithmic transformation: 
$\mathrm{SCS}=\log _{2}(\mathrm{SCC} / 100000)+3$. Lactation mean SCS was also computed for restricted lactation lengths ( 2 to 4 records): from DIM 25, 56 or 86 until the end of the lactation, and from DIM 25, 56 or 86 unitl DIM 145.

For the on-farm data set, five additional SCC traits were defined in the first lactation, based on single test-day SCS, according to DIM at test-day: 25-54 (SCS1), 55-84 (SCS2), 85-114 (SCS3), and 115-144 (SCS4), and 145-174 (SCS5). Generally, only one record per animal was available for each testday since the on-farm recording frequency is about once a month. When two records were available per ewe and per DIM interval, only the first one was kept.

Finally, production traits were considered in the on-farm data set. As for SCC, lactation means were computed for milk yield, fat content and protein content (DIM 25 until the end of the first lactation) and production traits were also considered at the test-day level (five traits defined according to DIM in the first lactation).

\subsection{Methods}

\subsubsection{Risk factors for mastitis traits (experimental flock data)}

Analyses of risk factors for mastitis traits (CCMAST and SUBMAST) were based on logistic regression models, using the CATMOD procedure [35]. For the SUBMAST trait, the dependent variable analysed was restricted to two levels: "infected" versus "doubtful or healthy". The fixed effects included in the models, i.e. potential risk factors for mastitis traits, were line (High or Low), number of suckled lambs (1 vs. 2 or more), year of lambing (1992 to 1997) and period of lambing (early $v s$. late). Early lambing corresponded to lambing in January after AI fertilisation upon induced oestrus, whereas late lambing took place in February or March and corresponded to natural fertilisation after return to oestrus.

The overall significance of each effect in the models was assessed by a Wald test. This statistic takes the form of a squared ratio of an estimate to its standard error and asymptotically follows an approximate chi-square distribution with one degree of freedom. Odds ratio (OR) and OR 95\% confidence intervals were computed according to Lemeshow and Hosmer [23]. OR measures how much more (or less) likely the outcome is among observations with a given level of a risk factor, compared with those with a reference level of the risk factor. For the four analysed effects, reference levels were High Line, one suckled lamb, early lambing, and lambing in 1994, respectively.

\subsubsection{Estimation of genetic parameters for SCC (on-farm data)}

The genetic parameters for the different SCC traits and the genetic correlation between SCC traits and production traits were estimated from the on-farm data 
set (5 272 first lactation ewes). Variance components were estimated by REML applied to multivariate animal models, using the VCE package [29]. For all traits, with 5 to 6 being analysed simultaneously, an animal model was used, and all ewes were included, whether they had records or not.

In a first analysis, the linear model describing complete and partial lactation traits for SCS, milk yield, fat and protein content was:

$$
y_{i j k l}=(\text { Flock } \times \text { Year })_{i}+\mathrm{Age}_{j}+\mathrm{Lambs}_{k}+a_{l}+e_{i j k l}
$$

where:

$(\text { Flock } \times \text { Year })_{i}=$ fixed effect of flock $\times$ year combination $i$ (68 levels);

Age $_{j} \quad=$ fixed effect of age at first lambing $j$ (6 levels: less than 395 days 396-410, 411-425, 426-440, 441-600, and 601920 days);

Lambs $_{k} \quad=$ fixed effect of the number of suckled lambs $k$ (2 levels: 1 vs. 2 or more);

$a_{l} \quad=$ random genetic effect of animal $l$;

$e_{i j k l} \quad=$ random residual effect.

In the second analysis, the five single test-day traits (1 to 5) defined according to DIM, for SCS, and the three production traits were considered as different traits in a multiple trait test-day model approach. The (flock $\times$ year) effect used in model (1) was replaced by a (flock $\times$ test-day) effect that allows to take into account short-time environmental variations. The model also included the effect of DIM of the record, and was:

$$
y_{i j k l m}=(\text { Flock } \times \text { Test-day })_{i}+\mathrm{DIM}_{j}+\mathrm{Age}_{k}+\operatorname{Lambs}_{l}+a_{m}+e_{i j k l m}
$$

where:
$(\text { Flock } \times \text { Test-day })_{i}=$ fixed effect of flock by test-day combination $i$ (385 levels);
$\mathrm{DIM}_{j} \quad$ = days in milk on test-day $j$ (15 levels: 2-day steps);
$\mathrm{Age}_{k} \quad=$ fixed effect of age at first lambing $k$ (6 levels: less than 395 days, 396-410, 411-425, 426-440, 441-600, and 601-920 days);
$\operatorname{Lambs}_{l} \quad \quad=$ fixed effect of the number of suckled lambs $l(2$ levels: 1 vs. 2 or more);
$a_{m} \quad=$ random genetic effect of animal $m$;
$e_{i j k l m} \quad=$ random residual effect.

In the third analysis, a repeatability model was performed. Test-day records of SCS, milk yield, fat and protein content between DIM 25 and 175 were assumed to be a repetition of the same trait. The repeatability model used was:

$$
y_{i j k l m n}=(\text { Flock } \times \text { Test-day })_{i}+\mathrm{DIM}_{j}+\mathrm{Age}_{k}+\operatorname{Lambs}_{l}+p_{m}+a_{n}+e_{i j k l m n}
$$


where:

$(\text { Flock } \times \text { Test-day })_{i}=$ fixed effect of flock by test-day combination $i$ (385 levels);

$\mathrm{DIM}_{j} \quad=$ days in milk on test-day $j$ (30 levels: 5 -day steps)

$\mathrm{Age}_{k} \quad=$ fixed effect of age at first lambing $k$ (6 levels: less than 395 days 396-410, 411-425, 426-440, 441-600, and 601-920 days);

Lambs $_{l} \quad=$ fixed effect of the number of suckled lambs $l(2$ levels: 1 vs. 2 or more);

$p_{m} \quad=$ random permanent environmental effect;

$a_{n} \quad=$ random genetic effect of animal $n$;

$e_{i j k l m n}=$ random residual effect

Two generations of ancestors were traced for the relationship matrix and the total number of animals was 13819 .

\section{RESULTS}

\subsection{Basic statistics}

Basic statistics are presented in Table II. The arithmetic mean of SCC was slightly lower for the experimental flock data (316000) than for the on-farm data (374 300), and the distribution of SUBMAST levels showed a comparable proportion of "infected" ewes (around 10\%).

From the on-farm data set, it can be pointed out that predicted "infected ewes" increased from $2.6 \%$ at test-day 2 to $5.4 \%$ and $9.2 \%$ on test-days 3 and 4, which results, to some extent, from the definition of SUBMAST (at least two test-day SCCs above 1000000 cells $\cdot \mathrm{mL}^{1}$ ). SUBMAST may be predicted for $90 \%$ of the "infected" ewes on the fourth test-day at about 120 days in milk. This trend was in agreement with the increase of SCS from the first to the fifth test-day, i.e. from 3.08 to 3.43 (Tab. III).

In the experimental flock, the first cause of culling from 1992 to 1997 was low milk production, with an average culling rate of $13 \%$. The second cause of culling was related to udder health: $5.3 \%$ of ewes in first lactation were culled (Tab. II) for either clinical or chronic mastitis (CCMAST). The clinical mastitis cases were followed either by rapid death or culling of the diseased animal. They occurred early in lactation, between lambing and the second month of lactation, and on average on day 32 after lambing (Tab. II). Chronic mastitis was detected by mammary palpation at mid- or late lactation. However, affected ewes were allowed to complete their lactation normally and were culled at a slightly anticipated dry-off at DIM 129 on average (Tab. II). Frequency of culling for clinical or chronic mastitis increased from $3.6 \%$ and 
$1.7 \%$, respectively, in the first lactation, to $3.9 \%$ and $4.3 \%$, respectively, in the third lactation (data not shown).

\subsection{Risk factors for mastitis traits (experimental flock data)}

Results of logistic regression analyses, investigating risk factors for CCMAST and SUBMAST mastitis traits, are presented in Table IV. The effect of the number of suckled lambs was not significant $(P>0.30)$ for any of the two traits. Risk factors identified for CCMAST were different from those identified for SUBMAST. The only highly significant effect on CCMAST was the period of lambing, and the risk of culling for mastitis increased for late lambings $(P<0.0001$; OR $=4.25)$. There was no significant difference between the two divergent lines $(P=0.69)$. On the contrary, for SUBMAST, there was a significant decrease of predicted "infected" ewes for the Low Line, when compared with the High line $(P=0.03$; OR $=0.58)$, showing a genetic antagonism between milk yield and subclinical mastitis resistance. The effect of year of lambing showed higher risks for both CCMAST and SUBMAST from 1995 to 1997 when compared with 1994, but was significant only for SUBMAST.

\subsection{Genetic parameters for SCC and production traits (on-farm data)}

\subsubsection{Heritabilities}

The heritability of adjusted annual LSCS was rather moderate (0.15) and lower than that of lactation milk yield (0.34), fat (0.50), and protein $(0.63)$ content (Tab. V).

Heritability estimates for single test-day SCS, considered as different traits according to DIM, were lower than the estimate for the lactation average (Tab. V). Heritabilities of SCS were especially low at the beginning of lactation (0.04 and 0.05 , for test-days 1 and 2, respectively) and increased for test-days 3 to 5 (0.09 to 0.12 ). The phenotypic standard deviation of test-day SCS was stable over DIM (Tab. VI). Thus the increase of SCS heritability with DIM reflected the doubling of the genetic standard deviation, from 0.33 to 0.60 SCS units between the first and the fourth test-day (Tab. VI) as well as the small decrease in the environmental standard deviation. The corresponding trends for single test-day production traits (Tab. V) showed an increase in heritability for fat content with DIM, little changes for protein content and maximum heritability on test-day 2 for milk yield (if we exclude the fifth test-day owing to the lack of data).

Heritability estimates of test-day SCS from the repeatability model was 0.08 (Tab. V). The corresponding phenotypic standard deviations (1.73) were very close to the values estimated from the multitrait approach while genetic 
Table IV. Risk factors for two mastitis traits in first lactation, expressed as odds ratio (OR) and 95\% confidence interval (CI) relative to ewes from the High line with early lambing in 1994 and with one suckled lamb.

\begin{tabular}{|c|c|c|c|c|c|c|}
\hline & \multicolumn{6}{|c|}{ Mastitis trait } \\
\hline & \multicolumn{3}{|c|}{$\mathrm{CCMAST}^{(1)}$} & \multicolumn{3}{|c|}{ SUBMAST $^{(1)}$} \\
\hline $\begin{array}{l}\text { Risk } \\
\text { factor }\end{array}$ & $P^{(2)}$ & $\mathrm{OR}^{(3)}$ & $95 \% \mathrm{CI}$ & $P^{(2)}$ & $\mathrm{OR}^{(3)}$ & $95 \% \mathrm{CI}$ \\
\hline Line & 0.6938 & & & 0.0302 & & \\
\hline High & & 1.00 & - & & 1.00 & - \\
\hline Low & & 1.13 & $0.74-2.64$ & & $0.58^{*}$ & $0.35-0.95$ \\
\hline Period of lambing & $<0.0001$ & & & 0.2857 & & \\
\hline Early & & 1.00 & - & & 1.00 & - \\
\hline Late & & $4.25^{*}$ & $2.25-8.05$ & & 0.77 & $0.47-1.25$ \\
\hline Year of lambing & 0.1282 & & & 0.0302 & & \\
\hline 1992 & & 0.54 & $0.13-2.33$ & & 1.64 & $0.66-4.08$ \\
\hline 1993 & & 1.88 & $0.63-5.72$ & & 1.17 & $0.45-3.07$ \\
\hline 1994 & & 1.00 & - & & 1.00 & - \\
\hline 1995 & & 2.87 & $0.99-8.31$ & & 2.03 & $0.85-4.89$ \\
\hline 1996 & & 1.61 & $0.53-4.88$ & & $2.45^{*}$ & $1.05-5.74$ \\
\hline 1997 & & 1.82 & $0.57-5.82$ & & $2.59^{*}$ & $1.11-6.07$ \\
\hline
\end{tabular}

(1) CCMAST = culling for clinical or chronic mastitis (level analysed: yes $v s$. no); SUBMAST $=$ prediction of the subclinical mastitis status of the udder from SCCs (level analysed: "infected" vs. "doubtful", "healthy" or no SCC available).

(2) $P=$ Global significance of variable (Wald statistics).

(3) OR significantly different from $1.0(P<0.05)$ are identified by an asterisk.

standard deviation (0.49) was similar to the value estimated for the lactation average (LSCS) (Tab. VI). Furthermore, the repeatability estimate (not shown) of SCS was 0.36, comparable to that of fat content (0.34) and smaller than that of protein content $(0.48)$ and milk yield (0.60).

Heritability estimates of partial lactation SCS traits (Tab. VII) were comparable to the estimate of the complete lactation mean $(0.15)$ and ranged from 0.12 to 0.15 depending on the partial lactation considered.

\subsubsection{Genetic and environmental correlations}

The genetic correlation between lactation SCS and lactation milk yield (Tab. V) was slightly positive (0.11), reflecting a moderate genetic antagonism between the two traits. However, a strong evolution of the genetic correlation between milk yield and SCS during lactation was observed. This correlation 
Mastitis resistance and SCC in dairy sheep

407

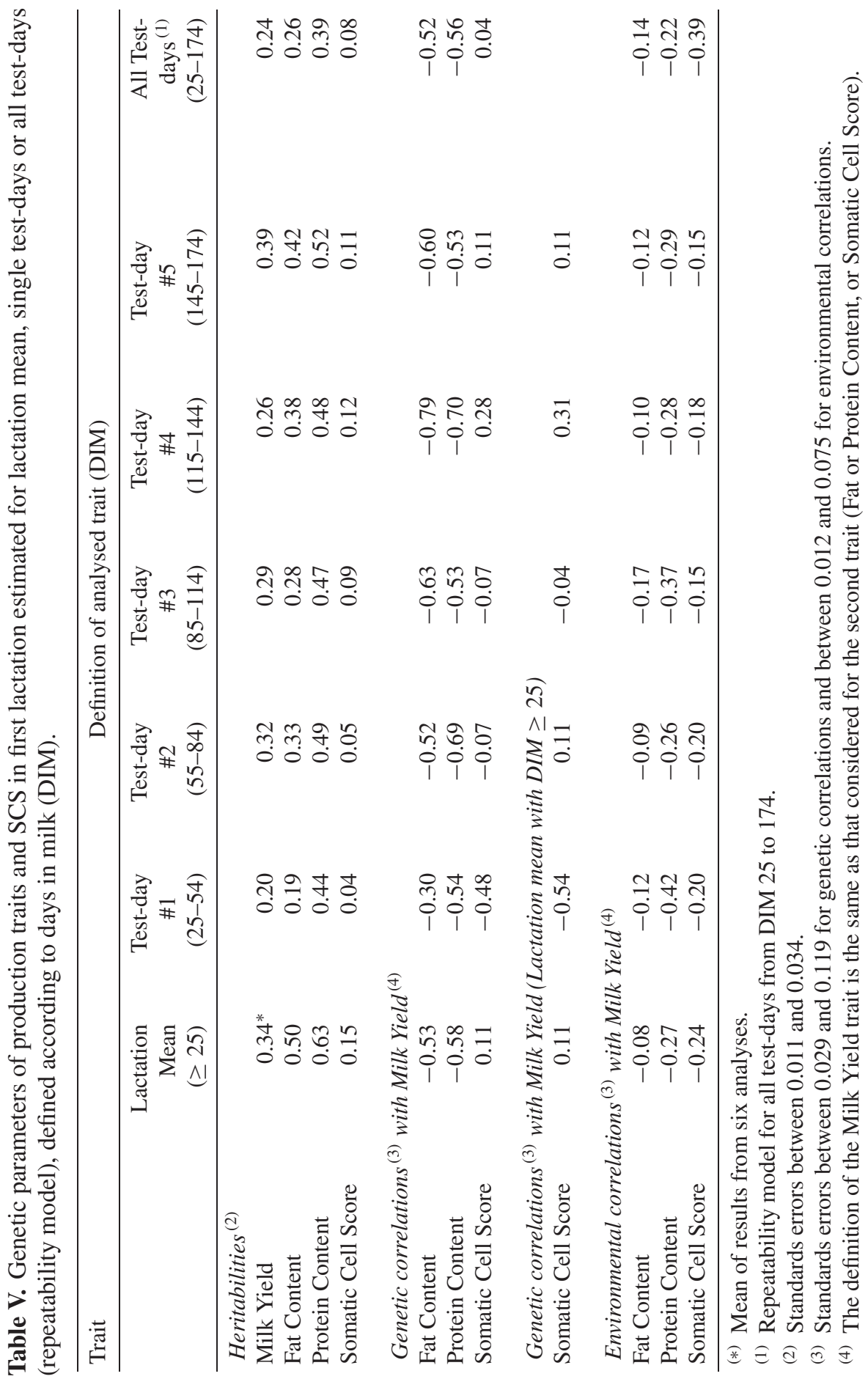




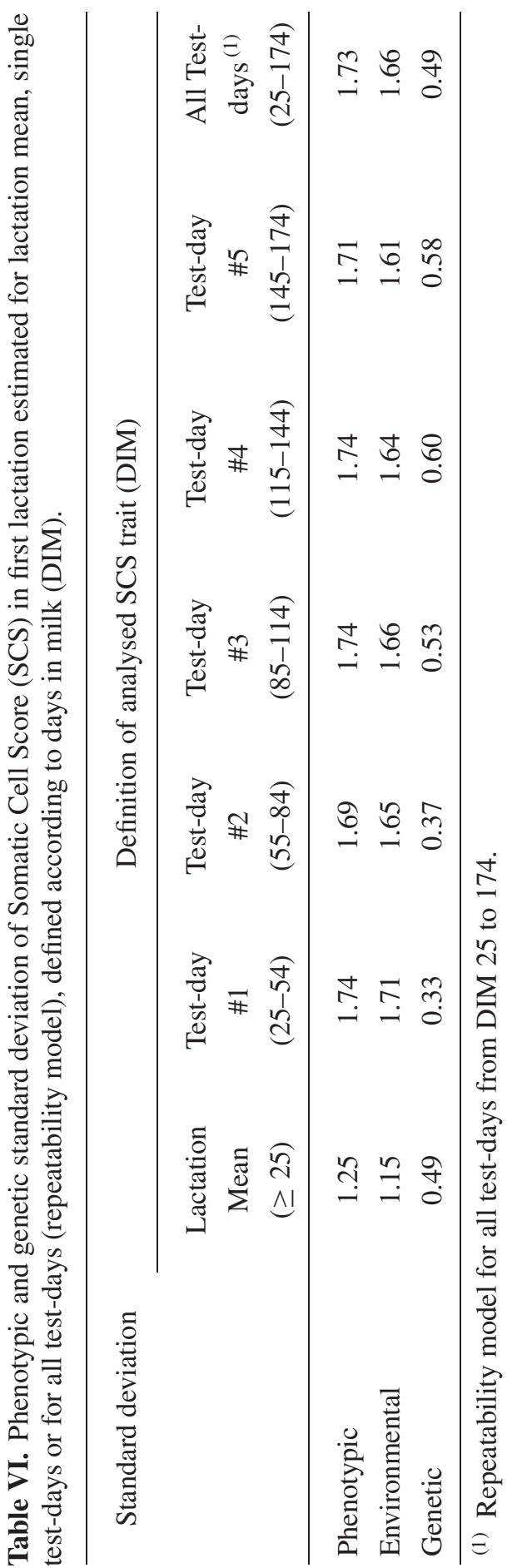


Table VII. Heritabilities of Somatic Cell Score (SCS) in first lactation estimated for lactation mean (LSCS) or partial lactation means according to day in milk (DIM), and genetic and environmental correlations with Milk Yield.

\begin{tabular}{|c|c|c|c|c|c|c|}
\hline & \multicolumn{6}{|c|}{ Definition of analysed SCS trait } \\
\hline & \multirow{2}{*}{$\begin{array}{c}\text { LSCS } \\
(\mathrm{DIM} \geq 25)\end{array}$} & \multicolumn{5}{|c|}{ Partial lactation mean SCS for DIM } \\
\hline & & $\geq 55$ & $\geq 85$ & $25-144$ & $55-144$ & $85-144$ \\
\hline $\begin{array}{l}\text { Heritabilities }^{(2)} \\
\text { Correlations } \\
\text { with Milk Yield }^{(1)}\end{array}$ & 0.15 & 0.13 & 0.14 & 0.12 & 0.12 & 0.14 \\
\hline Genetic $^{(3)}$ & 0.11 & 0.20 & 0.20 & 0.12 & 0.19 & 0.19 \\
\hline Environmental $^{(4)}$ & -0.24 & -0.18 & -0.14 & -0.19 & -0.17 & -0.13 \\
\hline
\end{tabular}

(1) Milk Yield trait defined as the mean of all test-days from DIM 25 to the end of lactation.

(2) Standards errors between 0.015 and 0.022 .

(3) Standards errors between 0.072 and 0.078 .

(4) Standards errors between 0.020 and 0.021 .

was favourable on the first test-day $(-0.48)$, low for test-days 2 to $3(-0.07)$, and became antagonistic ( 0.11 to 0.27$)$ from the fourth test-day onwards, i.e. after DIM 115 (Tab. V). This trend was confirmed by estimates of genetic correlation between lactation milk yield and test-day SCS, ranging from -0.54 to 0.31 (Tab. V). When the repeatability model was used (Tab. V), the estimated genetic correlation between milk yield and SCS was close to zero $(-0.04)$.

As expected, a clear antagonism was always observed between milk yield and fat or protein content, at test-day or lactation level (Tab. V).

Conversely to genetic correlation, the environmental correlations between SCS and milk yield (Tabs. V and VII) were always negative ( -0.13 to -0.39$)$ showing the unfavourable effect of subclinical mastitis on milk yield

The genetic correlation between the first four single test-day SCS (Tab. VIII) was very high $(>0.92)$. The fifth test-day SCSs were less correlated to the others, and the genetic correlation ranged from 0.74 to 0.81 .

\section{DISCUSSION}

In the experimental INRA Lacaune flock, the frequency of culling for clinical and chronic mastitis over a 6-year period was around 5\% in the first lactation, which is in agreement with other reports $[8,22]$. This frequency was clearly lower than the predicted frequency of mastitis based on SCC, which was equal to $10.4 \%$, and corresponded, excluding detected chronic cases, to $9.7 \%$ of fully subclinical infections. This value was comparable with estimates obtained in 
Table VIII. Genetic ${ }^{(1)}$ (above the diagonal) and environmental ${ }^{(2)}$ (below the diagonal) correlations between single test-day (SCS \#1 to SCS \#5) and lactation mean (LSCS) Somatic Cell Score traits in first lactation.

\begin{tabular}{lccccccc}
\hline Trait & (DIM) & SCS \#1 & SCS \#2 & SCS \#3 & SCS \#4 & SCS \#5 & LSCS \\
\hline SCS \#1 & $(25-54)$ & & 0.95 & 0.94 & 0.92 & 0.81 & 0.94 \\
SCS \#2 & $(55-84)$ & 0.37 & & 0.99 & 0.99 & 0.78 & 0.98 \\
SCS \#3 & $(85-114)$ & 0.34 & 0.36 & & 0.99 & 0.77 & 0.98 \\
SCS \#4 & $(115-144)$ & 0.38 & 0.37 & 0.41 & & 0.74 & 0.97 \\
SCS \#5 & $(145-174)$ & 0.39 & 0.40 & 0.43 & 0.42 & & 0.88 \\
LSCS & $(\geq 25)$ & 0.68 & 0.71 & 0.71 & 0.71 & 0.71 & \\
\hline
\end{tabular}

(1) Standards errors between 0.006 and 0.084 .

(2) Standards errors between 0.008 and 0.015 .

other Lacaune flocks with the same SCC levels [22]. Thus intramammary infections in dairy sheep are characterised by a lower incidence of clinical mastitis than in dairy cattle, reported to be between $20 \%$ and $40 \%[20,27,33]$.

Additionally, conversely to the risk of subclinical infection, no significant difference in the risk of culling for clinical or chronic mastitis was found between the two divergent lines selected for milk yield in the experimental INRA flock. These results suggest that selection for production traits in ewes may not have been accompanied by a substantial increase of clinical and chronic mastitis occurrence as reported for dairy cattle $[13,38]$. However, given the low frequency of clinical mastitis, its heritability which is probably very low according to cattle literature $[28,33]$, and the limited amount of data, further investigations would be necessary to confirm this trend.

In practice, improving udder health in dairy ewes would make it possible to focus, at least for the moment, on selection against subclinical mastitis using somatic cell counts. Indeed, subclinical infections appear as the main udder pathology. Moreover, no on-farm recording of clinical cases is available for dairy sheep and this is probably difficult to promote on a large scale due to the rather low incidence of such cases.

Using different models, we estimated genetic parameters of SCC as well as relationships with production traits. Genetic parameters of production traits were consistent with sheep literature $[3,4,34]$. The heritability estimate of lactation mean SCS of 0.15 was in agreement with the only available value of 0.12 estimated in ewes [17] and with the average value of 0.15 provided by more recent studies in dairy cattle $[10,27,33]$. The genetic correlation between lactation SCS and milk yield in first lactation was slightly positive (0.11), in agreement with results from dairy cattle data [10,27,33]. El Saied et al. [17], however, found a negative and favourable genetic correlation $(-0.15)$ between lactation SCC and milk yield in the ovine Churra breed. This discrepancy could 
be due to differences in modelling and in the nature of SCC data analysed. Indeed, the latter authors included information from all parities, over a rather short lactation period (2.7 test-day records per lactation), using a repeatability model for the lactation mean. The slightly unfavourable genetic relationship between SCC and milk yield found in our study was in agreement with the results of the experimental flock. Indeed, there was a significant difference in the risk of being predicted as infected (according to SUBMAST using SCC) between the two divergent lines selected for production in the experimental flock.

Consequently, the results obtained on a lactation basis were very similar to the abundant information available on dairy cattle. Therefore, similarly, the conclusion can be drawn that selection for mastitis resistance via somatic cell counts is feasible, justifying the inclusion of the lactation SCC trait in breeding programmes. One limiting problem is that an exhaustive monthly recording of SCC is not available on a large scale in French dairy sheep. A generalised simplified method of SCC sampling, however, has been implemented since 1999, as for fat and protein content data [2], in order to obtain a large number of recorded animals at a reduced cost. Since genetic parameters for SCC were similar for partial and for total lactation length periods, the use of means of only 2 or 3 test-day SCC per lactation between the four first test-days in genetic evaluation procedures should also be valid.

The evolution of the genetic determinism of SCC during lactation and its relationship with production, however, is less consistent throughout literature on sheep and cattle. Heritability estimates increased with day in milk from 0.04 to 0.12 and was especially low for the first two records, resulting in a strong increase in genetic variance at the end of the lactation. Similarly, in sheep, Baro et al. [6], estimated very low heritabilities for SCS measured during the first (0.01) and second month (0.05), and a higher value for SCS measured during the third month (0.11). In dairy cattle, comparable studies [11,12,28, 31,32] reported a generally smaller increase in heritability with DIM (ranging from 0.08 to 0.14 ) with higher values in the first months of the lactation.

Moreover, a strong evolution of the genetic relationship between SCC and milk yield was observed during the first lactation. Comparable analyses available in dairy cattle show opposite trends. Indeed, Carnier et al. [11], Reents et al. [31] and Rupp [32], indicate antagonistic genetic correlations between SCC and milk yield at the beginning of lactation, which tend to be weaker at the end of lactation. Thus, comparable results on a lactation basis for cows and sheep, i.e. little antagonism, reflect different evolutionary trends through lactation.

Differences in the etiology of infections but also in management systems according to species, such as the suckling period specific to dairy sheep, may explain, to some extent, differences in genetic parameters (heritabilities, 
genetic correlations). The effect of suckling on udder health is an ongoing research topic on dairy sheep, since it could be protective against mastitis (unpublished results). Our results should be confirmed because of rather spare and inconsistent data on the genetic correlation between milk yield and SCC, and further investigations within and across lactations are required.

\section{CONCLUSION}

According to the low clinical mastitis frequency, selection for mastitis resistance in dairy sheep could, at the moment, be limited to selection against subclinical mastitis. Such selection may be achieved using the indirect SCC trait since genetic parameters were similar to dairy cattle estimates on a lactation basis.

Results, however, showed a strong evolution of the genetic determinism of SCC and of the genetic relationship between SCC and milk yield (from favourable to antagonistic) during the first lactation. Further within- and acrosslactation analyses are necessary to validate these results which differ from dairy cattle literature. If this is confirmed, replacing an SCC genetic evaluation based on a lactation approach, by a test-day approach could be justified in dairy sheep.

\section{ACKNOWLEDGEMENTS}

This work was supported by a French (MESR 94 G 0303), then European contract (FAIR CT 95 0881). We gratefully acknowledge the staff of the INRA La Fage farm and the technicians from the Confédération Générale de Roquefort, EDE 81 and UNOTEC who set up the on-farm experimental recording of SCC.

\section{REFERENCES}

[1] Ali A.K.A., Shook G.E., An optimum transformation for somatic cell concentration in milk, J. Dairy Sci. 63 (1980) 487-490.

[2] Barillet F., Amélioration génétique de la composition du lait des brebis : l'exemple de la race Lacaune. Ph. D thesis, INA-PG/INRA, 1985.

[3] Barillet F., Genetics of Milk Production, Chap. 20, in: Piper I., Ruvinsky A. (Eds.), The Genetics of Sheep, CAB International, 1997, pp. 539-564.

[4] Barillet F., Boichard D., Studies on dairy production of milking ewes. I. Estimates of genetic parameters for total milk composition and yield, Génét. Sél. Evol. 19 (1987) 459-474.

[5] Barillet F., Boichard D., Astruc J.M., Bonaïti B., Validation of estimated genetic trend in French Lacaune dairy sheep evaluation, in: Proceedings of the 30th biennial session of ICAR, Veldhoven, The Netherlands, 23-28 June 1996, EAAP Publication No. 87, pp. 291-298. 
[6] Baro J.A., Carriedo J.A., San Primitivo F., Genetic parameters of test-day measures for somatic cell count, milk yield and protein percentage of milking ewes, J. Dairy Sci. 77 (1994) 2658-2662.

[7] Bergonier D., van de Wiele A., Arranz J.M., Barillet F., Lagriffoul G., Condorcet D., Berthelot X., Detection of subclinical mammary infections in the ewe by mean of somatic cell counts: proposal of physiological thresholds, in: Proceedings of the International symposium on somatic cells and milk of small ruminants, Bella, 25-27 September 1994, Italy, EAAP Publication No. 77, pp. 41-47.

[8] Bergonier D., Blanc M.C., Fleury B., Lagriffoul G., Barillet F., Berthelot X., Les mammites des ovins et caprins laitiers : étiologie, épidémiologie, contrôle, Rencontre Rech. Rumin. 4 (1997) 251-260.

[9] Bergonier D., Berhelot X., Romeo M., Contreras A., Coni V., de Santis E., Roselu S., Barillet F., Lagriffoul G., Marco J., Fréquence des différents germes responsables de mammites cliniques et subcliniques chez les petits ruminants laitiers, in: 6th International symposium of the milking of small ruminants, Athens, 26 September-1st October 1998, Greece, EAAP Publication No. 95, pp. 130-136.

[10] Boettcher P.J., Dekkers J.C.M., Kolstad B.W., Development of an udder health index for sire selection based on somatic cell score, udder conformation, and milking speed, J. Dairy Sci. 81 (1998) 1157-1168.

[11] Carnier P., Bettella R., Cassandro M., Gallo L., Mantovani R., Bittante G., Genetic parameters for test-day somatic cell count in Italian Holstein Frisian cows, in: Proceedings of the 48th Annual meeting of the European association for animal production, Vienna, 25-28 August 1997, p. 141 (Abstract).

[12] Charffeddine N., Alenda R., Carabano M.J., Relationships between somatic cell score and longevity, production and type traits in Spanish Holstein-Frisian cows, in: Proceedings of the 48th Annual meeting of the European association for animal production, Vienna, 25-28 August 1997, p. 32 (Abstract).

[13] Colleau J.J., Le Bihan-Duval E., A simulation study of selection methods to improve mastitis resistance of dairy cows, J. Dairy Sci. 78 (1995) 659-671.

[14] Cosseddu A.M., Spissu A., de Santis E.P.L., Mazette R., Some microbiological causes for the increase in somatic cells in sheep milk, in: Proceedings of the International symposium on somatic cells and milk of small ruminants, Bella, 25-27 September 1994, Italy, EAAP Publication No. 77, pp. 85-88.

[15] De la Cruz M., Serrano E., Montoro V., Marco J., Romeo M., Baselga R., Albizu I., Amorena B., Etilogy and prevalence of subclinical mastitis in the Manchega sheep at mid-late-lactation, Small Rum. Res. 14 (1994) 175-180.

[16] El Saied U.M., Carriero J.A., San Primitivo F., Heritability of test-day somatic cell counts and its relationship with milk yield and protein percentage in dairy ewes, J. Dairy Sci. 81 (1998) 2956-2961.

[17] El Saied U.M., Carriero J.A., de La Fuente L.F., San Primitivo F., Genetic parameters of lactation cell counts and milk and protein yield in dairy ewes, J. Dairy Sci. 81 (1999) 2956-2961.

[18] Emanuelson U.F., Danell B., Philipsson J., Genetic parameters for clinical mastitis, somatic cell counts, and milk production by multiple-trait restricted maximum likelihood, J. Dairy Sci. 71 (1988) 467-476. 
[19] Flamant J.C., Poutous M., Aspects quantitatifs de la production laitière des brebis. VII : Précision d'un contrôle laitier alterné (AT) et d'un contrôle laitier d'alternance quelconque corrigé pour les écarts moyens entre les performances du soir et du matin (AC), Ann. Génét. Sél. Anim. 2 (1970) 65-73.

[20] Heringstad B., Karlsen A., Klemetsdal G., Ruane J., Preliminary results from a genetic analysis of clinical mastitis data, Interbull Bull. No. 15 (1997) pp. 45-49.

[21] ICAR, International regulations for milk recording in Sheep. Institut de l'élevage, Paris, 1992.

[22] Lagriffoul G., Barillet F., Bergonier D., Berthelot X., Jacquin M., Relation entre les comptages de cellules somatiques du lait du troupeau et la prévalence des mammites subcliniques des brebis estimées avec les comptages de cellules somatiques individuels, in: 6th International symposium of the milking of small ruminants, Athens, 26 September-1st October 1998, Greece, EAAP Publication No. 95, pp. 151-156.

[23] Lemeshow S., Hosmer D.W. Jr., Estimating odds ratios with categorically scaled covariates in multiple logistic regression analysis, Am. J. Epidemiol. 119 (1984) $147-158$.

[24] Lund T., Miglior F., Dekkers J.C.M., Burnside E.B., Genetic relationships between clinical mastitis, somatic cell count, and udder conformation in Danish Holsteins, Livest. Prod. Sci. 39 (1994) 243-255.

[25] Mavrogenis A.P., Koumas A., Kakoyiannis C.K., Taliotis C.K., Use of somatic cell counts for the detection of subclinical mastitis in sheep, Small Rum. Res. 17 (1994) 79-94.

[26] Mavrogenis A.P., Koumas A., Gavrielidis G., The inheritance of somatic cell counts (index of mastitis) in Chios sheep, in: 6th International symposium of the milking of small ruminants, Athens, 26 September-1st October 1998, Greece, EAAP Publication No. 95, pp. 389-392.

[27] Mrode R.A., Swanson G.J.T., Genetic and statistical properties of somatic cell count and its suitability as an indirect means of reducing the incidence of mastitis in dairy cattle, Anim. Breed. Abstract 64 (1996) 847-857.

[28] Mrode R.A., Swanson G.J.T., Winters M.S., Genetic parameters and evaluations for somatic cell counts and its relationship with production and type traits in some dairy breeds in the United Kingdom, Anim. Sci. 66 (1998) 569-576.

[29] Neumaier A., Groeneveld E., Restricted Maximum Likelihood estimation of covariances in sparse linear models, Genet. Sel. Evol. 30 (1998) 3-26.

[30] Pellegrini O., Aurel M.R., Lagriffoul G., Marie C., Remeuf F., Rivemale M., Barillet F., Relations entre les comptages de cellules somatiques, les caractéristiques physico-chimiques et l'aptitude à la coagulation par la présure de laits individuels de brebis de race Lacaune, in: Proceedings of the International symposium on somatic cells and milk of small ruminants, Bella, 25-27 September 1994, Italy, EAAP Publication No. 77, pp. 253-258.

[31] Reents R., Jamrozik J., Schaeffer L.R., Dekkers J.C.M., Estimation of genetic parameters for test-day records of somatic cell score, J. Dairy Sci. 78 (1995) 2847-2857.

[32] Rupp R., Analyse génétique de la résistance aux mammites chez les ruminants laitiers, P-141-150. Ph. D thesis, INA-PG/INRA, 2000. 
[33] Rupp R., Boichard D., Genetic parameters for clinical mastitis, somatic cell score, production, udder type traits, and milking ease in first lactation Holsteins, J. Dairy Sci. 82 (1999) 2198-2204.

[34] Sanna S.R., Carta A., Casu S., (Co)variance component estimates for milk composition traits in Sarda dairy sheep using bivariate animal model, Small Rum. Res. 25 (1997) 77-82.

[35] SAS $^{\mathrm{R}}$ Institute, SAS ${ }^{\mathrm{R}}$ /STAT User's Guide, Version 6, Vol. 1, 4th Edn. SAS ${ }^{\mathrm{R}}$ Institute Inc., Cary, NC, 1989.

[36] Schoder G., Baumgartner W., Pernthaner A., Variation of somatic cell counts in sheep and goat milk during the lactation period, in: Proceedings of the 5th Symp. on machine milking of small ruminants, Budapest, 14-20 May 1993, pp. 99-107.

[37] Seegers H., Menard J.L., Fourichon C., Mammites en élevage bovin laitier : importance actuelle, épidémiologie et plans de prévention, Rencontre Rech. Rumin. 4 (1997) 233-242.

[38] Strandberg E., Shook G.E., Genetic and economic responses to breeding programs that consider mastitis, J. Dairy Sci. 72 (1989) 2136-2142.

[39] Wiggans G.R, Shook G.E., A lactation measure of somatic cell count, J. Dairy Sci. 77 (1987) 2666-2672.

To access this journal on line: www.edpsciences.org 